lem that these institutions will need to resolve. Committed as they are to human resource development, private colleges and universities must remain sites for the pursuit of truth, something that cannot be reduced to job placement but instead must promote the discovery of new scientific answers to the pressing problems of contemporary society.

\section{Private Higher Education in Central Asia}

\section{Bermet Tursun Kulova}

Bermet Tursunkulova is deputy director of Civic Education-Central Asia and Mongolia. Address: 199 Tynystanov Str., Suite 7, Bishkek 720040, Kyrgyzstan. E-mail: cepcadcd@elcat.kg.

$\mathrm{T}$ he Central Asian republics have had much in common in terms of their culture and history, from the age of nomadic tribes to independence in I99I. Under the Soviet Union, all Central Asian republics and Mongolia functioned as centrally planned economies. Higher education, especially in the sciences, was considered to be a system of high standard. The Soviet Union's collapse was followed by discombobulating economic and social repercussions in the newly independent countries, including the education system. As in many other postcommunist countries, a large number of private universities were established. However, while some argue that these new universities challenged the existing state universities and the educational system in general, in Central Asia, most of the newly opened schools had but one purpose: to generate money for the owners or founders. This main orientation of the new private institutions has had a negative effect on the social stature of the private sectors in the region.

\section{State Control}

Higher education policies and regulations are similar in much of this region. The exception is Turkmenistan, where no private institutions of higher education exist. The so-called state patrons-consisting of the president of Turkmenistan, deputy chairman of the government, and all the ministers-supervise and monitor higher education institutions in Turkmenistan. The patrons are also responsible for student admissions and the employment of graduates.

Officially, no private higher education institutions existed in Uzbekistan until recently either, because there was no legislation permitting private education in that country. In a situation that is not uncommon internationally, some unlicensed nonstate institutions existed de facto; their diplomas were not officially recognized. The most famous of these institutions is the International Business School Kelajak Ilmi (literally translated from Uzbek as "future knowledge") in Tashkent. On March 3, 2004 the new governmental regulation on the licensing of nongovernmental educational institutions came into force. The International Business School managed to receive a license and now functions legally.

Thus, Uzbekistan joined Kazakhstan, Kyrgyz Republic, Mongolia, and Tajikistan as countries where legislation permits the creation of both state and nonstate higher education institutions. Kazakhstan, Kyrgyz Republic, and Mongolia have the largest number of private universities. For example, Kazakhstan has II4 private universities and 50 state universities, and Mongolia has 29 private universities, while Tajikistan has only 2 (official) nonstate universities.

As mentioned above, there are many similarities in the laws regulating private higher education in the region. The key document in each country is the education law. The other common feature is that the ministry of education regulates the educational system of each country. Also, several governmental agencies (various commissions, inspection agencies, etc.) enforce the law. The law stipulates provisions on licensing and accreditation of higher education institutions. Both licensing and accreditation are carried out by state inspection at least once every five years.

The state remains the only significant source of funding for the state universities and largely controls them.

The state remains the only significant source of funding for the state universities and largely controls them. The state also controls private institutions-to some extent because the ministry issues licenses to such universities. Nonstate universities can start functioning only if they receive such licenses from the state. In order to receive the license, an institution needs to comply with the set of norms-including a certain number of qualified full- and part-time staff and space provision for staff, students, libraries, among other things. The ministry and other government agencies define this set of norms. The ministry also approves the curricula, syllabi, and textbooks. Institutions can recruit and enroll students only if they have a license. Higher education institutions are obliged to show a student candidate this license and all other relevant documentation. Besides awarding the license, the ministry also recognizes all qualifications earned by the students. Requirements for the (bachelor's and master's) thesis and final (state) exams should comply with the ministerial educational standards.

\section{What To Do}

In summary, the state has significant power, with leverage, in relation to private universities. Yet universities suffer from a lack of funding and of resources to employ enough full-time staff to enforce the ministry's specifications. Although it is legitimate for a private higher education institution to exist, according to local legislation, it is difficult to determine what really defines private institutions. Certain actions might be implemented to clarify the situation. Independent accredita- 
tion centers could be established. At present, ministries of education lack the capacity to license and assess higher education institutions. The sources of financing could be diversified and schools encouraged to raise and manage extra funds. Curriculum specialists and other experts in education could be trained, with student-centered approaches to teaching and curriculum reforms that have been implemented in other countries. The skills of experts in higher education administration could also be strengthened. International organizations might lobby governments to support the growth of private higher education in the region. Without these improvements, it will be hard if not impossible for competitive private higher education of high quality to exist. The contemporary reality is that impressive growth has resulted in private higher education sectors that remain in precarious condition.

\section{Polish Private Higher Education: Expanding Access}

\section{Wojciech Duczmal}

Wojciech Duczmal is a research associate at the Management and Administration Academy in Opole, Poland, and a doctoral student at the Center for Higher Education Policy Studies, University of Twente, Netherlands. E-mail: rektorat@wszia.opole.pl.

$\mathrm{U}$ ntil I989, Polish higher education constituted an elite system with very low enrollment rates. The strong involvement of central political institutions in issues of higher education eliminated academic freedom and weakened the standing of Polish higher education institutions. A stagnant economy, the inflexibility of the higher education system, the weak correlation between higher education and employment, and low levels of faculty remuneration in the I980s discouraged many eligible students from participating in higher education and forced many bright academics to leave the country in search of better job prospects abroad.

\section{Reforms and Changes}

The transition period began in I989. The economic crisis at the start of the I990 exacerbated the falling industrial production, inflation (approaching I50 percent), and high unemployment rates. In response to the economic downturn, a set of economic reforms were introduced.

Higher education policy was also changed to allow institutions to restructure and adjust to the new economic, social, and political situation. A higher education law passed by Parliament in 1990 provided the basis for far-reaching changes. Major innovative provisions included the devolution of authority from the government to institutions, the introduction of tuition fees, and - crucial to this article-elimination of barriers of entry to private higher education institutions. These changes led to a substantial expansion of the higher education system in the I990s, in particular of the private sector.

Indeed, the most radical change was the permission to establish private higher education institutions. Before 1989 there was only one private higher education institution-the Catholic University of Lublin, established in I9I8, funded by the Church and the people of Poland. Under the new law, founders could establish nonpublic higher education institutions, once they meet the requirements set by the Ministry of Education, which included issues such as the number of professors, the curriculum, and infrastructure. Since 200I the minister has requested the approval of a State Accreditation Commission. Private institutions founded under the 1990 higher education act were allowed to offer bachelor's and master's degree programs. In I997, a vocational higher education schools act was passed by Parliament. New private institutions, established after I997, are registered as vocational higher education schools and can offer only bachelor's degree programs. In order to apply for master's degrees they have to change their status first and operate under the I990 higher education act. For this reason, the 145 most recently established private higher education institutions have the status of vocational institutions.

\section{Private institutions do not receive any direct state support for teaching and research.}

\section{Private-Sector Development}

Private institutions charge tuition fees for all their students; the fees are on average between 400 and 600 euros per semester. Private institutions do not receive any direct state support for teaching and research, although the government exempts private higher education institutions from property, sales, and income taxes. Until 2003, the state provided working students or their parents with deductions against state income tax liabilities for fees paid to higher education, but in 2004 this tax deduction was abolished.

Since 200I full-time students in the private sector have been eligible for state means-tested scholarships. In 200I about 17,000 students received state scholarships, which amount to about 50 euros a month. However, private-sector students are excluded from merit-based state scholarships. Since I998 all students enrolled in full-time or part-time studies have been eligible for state-subsidized loans.

Private higher education has rapidly expanded and gained increased acceptance. Private institutions play an important role in meeting the demand for higher education, which increased dramatically in the I990s, due to demographic factors and the rising importance of higher education for the labor market. The number of private providers rose from 3 in I990 to 280 in 2004, while student numbers rose from about 6,500 in I990-1991 to about 510,000 in 2003-2004, while 